\title{
Bulgarian Refugees from the Former Soviet Union: A Troubled Return
}

\author{
Kustodinova Iordanova
}

In recent years, Bulgaria has been a source of unprecedented out-migration for two reasons. First, a large number of ethnic Turks were expelled in 1989 and their emigration is still continuing. Second, political and economic turmoil in Bulgaria have caused a large wave of emigration. In May 1992,MinkoMinkov, the director of the Sofia's Demographic Institute, estimated the recent out-migration to be $400,000^{1}$, although he admitted that the actual figures would be known only after a census in early $1993 .^{2}$

Besides being a sending country, Bulgaria has also gradually become a receiving country for refugees, some of whom from the former Yugoslavia or from Third World countries consider Bulgaria only a temporary stopover in their long journey to the West. However, for others, Bulgaria is a final destination. These are mostly members of the Bulgarian ethnic minority from the former Soviet Union, who have decided to return to the land of their ancestors. Bulgarians are similar to many other minority groups from this region. As noted by Brubaker, there will be increased "pressure on other states with substantial numbers of co-ethnics in the former Soviet Union-notably Poland, Greece, Korea, Finland, Hungary and Bulgaria-to grant 'their' people preferential immigration and citizenship status." ${ }^{3}$ But little has been done to date by Bulgarian authorities who, due to the country's economic problems, seem reluctant to assist arriving refugees. While the government has been slow in setting up policies and procedures for Bulgarians fleeing from the former Soviet Union, some nationalist groups from the areas with ethnic unrest provide shelter for the newcomers, thus

\footnotetext{
Kustodinova Iordanova is a visiting scholar at the Women's Studies Program, University of
} Ottawa. strengthening the Bulgarian presence in these regions.

Bulgarians settled in Moldova, Ukraine and southern Russia during the five centuries of Ottoman domination, particularly in the nineteenth century. According to the 1989 census, there was a total of 372,941 ethnic Bulgarians in the U.S.S.R. Most of them-233, 000-lived in Ukraine. In Moldova there was a residential community of 89,000 Bulgarians in the so-called Budjak area in Southern Bessarabia, between the Prut and Dniester rivers. There were about 33,000 Bulgarians in Russia and approximately 16,000 in Central Asia. Most of the latter, together with other nationalities, were forced to move there from Crimea during the Stalinist era. ${ }^{4}$ There are also Bulgarian communities even at the Far East island of Sakhalin.

In 1991 some scholars began discussing the Bulgarian exodus. Kuzin wrote that even though neither Moldovan nor Ukrainian Bulgarians had direct access to Bulgaria, theirjourney through Romania was not impossible to imagine, given a perceived or real peril brought about by conditions in the U.S.S.R. ${ }^{5}$ Until now there has been no exodus of Bulgarians from Ukraine. Reports on Ukraine do not mention significant problems experienced by the Bulgarian minority there. Instead, they point to the establishment of basic cultural facilities among ethnic Bulgarians and attempts to harmonize interethnic relations. ${ }^{6}$

However, recent developments in some other areas have driven many people of Bulgarian descent from the troubled territories. These people seek resettlement in Bulgaria. Most refugees flee areas of ethnic clashes in Moldova and Tadjikistan. According to Ivan Doundarov, chairman of the Union of Bessarabian and Tauric Bulgarians, in the first half of 1992 over 200 families arrived from Bessarabia, 2,000 from
Tadjikistan, and another 3,000 families were expected to come from Bessarabia by early $1993 .^{7}$

The situation of Bulgarians in the Moldovan conflict differs from that of the Gagauz minority. ${ }^{8}$ While only 17 percent of Gagauz approve of President Mircha Snegur, as many as 70 percent of Bulgarians approve of him, ${ }^{9}$ yet others have switched their loyalties. Whereas they supported the Moldovan state in the past, they have gradually become supporters of the independent Dniester republic. Some Bulgarians were victims in the June and July 1992 clashes in Bendery, where about 5,000 Bulgarians live. According to some reports, more than fifty Bulgarians were killed in the conflict. ${ }^{10}$ The Bulgarian town of Parkani was constantly caught in a cross-fire. This has moved the Bulgarian government to protest ${ }^{11}$ and to send a 5 million leva (about Can. $\$ 250,000$ ) in aid to the town's 11,000 Bulgarian-speaking residents. Furthermore, some Bessarabian Bulgarians have been drafted against their will to fight against other Bulgarians on the Ukrainian side of the Dniester region conflict. Emigration to Bulgaria was seen as a solution to many Bulgarians caught in this interethnic clash.

The current Bulgarian citizenship law dates back to 1968. Eligibility is based on the proof of Bulgarian descent and knowledge of the Bulgarian language. It is difficult for Bessarabian Bulgarians to acquire citizenship, partly because in most cases they have no available documents to prove their Bulgarian origin. Furthermore, they are not sufficiently proficient in Bulgarian. "Until now not a single application for citizenship received from Bulgarians has been approved," reported Nora Dimova in July 1992. She predicted a large refugee wave from the Dniester region, but she observed that the Bulgarian government was not ready to deal with it. ${ }^{12}$ 
The Bulgarian press has reported that some 8,000 ex-Soviet Bulgarians have applied for Bulgarian citizenship. ${ }^{13}$ Most of them felt sceptical of their chances of receiving it soon. ${ }^{14}$ In the meantime, they were not entitled to work and had to depend entirely on the generosity of local people, who themselves were experiencing economic difficulties. The Bulgarian press has also reported that a growing number of students from Bessarabia were studying in Bulgarian secondary and postsecondary institutions. This was seen as a temporary alternative solution to seeking asylum. According a BBSS International Gallup poll that surveyed 1,461 Bulgarians living in Moldova and Ukraine, 64 percent of the respondents believe that Bulgaria cares about them, but only 26.4 percent hope to acquire Bulgarian citizenship, and 56 percent of the respondents have expressed interest in sending their children to school in Bulgaria. ${ }^{15}$

"Doomed to oblivion by the pro-Soviet totalitarian regime for many years in the past, Bulgarians living in the former red empire today are getting more and more attention from the state and public circles in Bulgaria," wrote B. Nyagulov. ${ }^{16}$ It seems, however, that the state and the public's views about assisting Bulgarians who are fleeing from the former Soviet Union differ significantly. The government seems more concerned about protecting ethnic minority rights of Bulgarians in the former Soviet Union, rather than assisting arriving refugees. The Bulgarian government has signed agreements on guaranteeing the preservation of the Bulgarian culture with Russia (in August 1992), Moldova (in September 1992) and Ukraine (in October 1992). According to some reports, in September 1992 the Bulgarian government decided to createan agency responsible for outlining state policies for Bulgarian refugees. ${ }^{17}$ However, given the resignation of the UDF government in November 1992, the two-month-long parliament crisis and the recent appointment of a new government, supported mostly by pro-communist forces, the creation of an effective institution to deal with the problems of refugees might very well remain only a good intention.
At the same time, some public sectors have started demanding a quick radical solution to the growing refugee crisis. There is widespread criticism of the government's failure to respond to refugee issues. At a September meeting of the Independent Public Committee for $\mathrm{Na}$ tional Issues, most of the participants expressed concern about Bulgaria's unpreparedness to receive large groups of ethnic Bulgarians. ${ }^{18}$ They argued that steps taken to promote ethnic culture in Terakliya (Moldova), Bolgrad (Ukraine), and in Caribrod (Serbia) ${ }^{19}$ were inadequate. Rodolyubetz, a group of nationalist Bulgarian intellectuals, is gaining force. ${ }^{20}$ In November 1992, 2,000 of its members signed a petition requesting that the government grant citizenship to those Bulgarians from Bessarabia and Tavria who wish to apply for it. They insisted that ethnic Bulgarian refugees be admitted to the country and provided with settlement assistance. They also requested that the Ministry of External Affairs negotiate financial compensation for refugees for the properties they left behind and that duty charges be waived for any belongings they may wish to bringinto the country. ${ }^{21}$ Velko Valkanov, an independent candidate at the 1992 presidential election and a well-known nationalist who enjoys the support of ex-communists, suggested that refugees of Bulgarian descent be allowed to stay in the country without any restrictions imposed on them as foreigners, and that they be eligible for citizenship. His other proposal included settling them in areas designated by the state..$^{22}$

While intellectuals pressure the government into providing recognition of and assistance to Bulgarian refugees, other organizations have tried to help these people. It seems that the nationalist organizations take the problems of the refugees most seriously. In their view, helping ethnic Bulgarians from the former Soviet Union to settle in Bulgaria is not only a patriotic duty but also a way to strengthen the Bulgarian population in areas of tension with ethnic Turks. Newspaper reports indicate that newly arrived refugees from Moldova and Tadjikistan receive assistance from the local population and settle mostly in areas like Kurdjali, Krumovgrad, Ivailovgrad, Haskovo, Pliska, Shoumen and Dobrich; that is, areas where most ethnic Turks live. At a July 1992 press conference in Kurdjaly, Bessarabian Bulgarian refugees noted that the only organization that defended their interests was the extreme nationalist All-National Committee for Defence of National Interests. ${ }^{23}$ Similarly in another region with a large Turkish population, Haskovo, members of this organization helped Bulgarians fleeing ethnic war in Dushanbe, Tadjikistan, in August 1992. ${ }^{24}$ This creates resentment among ethnic Turks. According to Major Ivan Toshev, the presence of ethnicBulgarian refugees "was met with suspicion by certain political forces." Among them is the Movement for Rights and Freedoms, the party of ethnic Turks, which has considerable political clout in the region..$^{25}$

So while the government has put off resolving the problems of ethnic Bulgarian refugees, nationalist groups have been most generous in offering assistance to them, which may provoke conflicts between the refugees and ethnic Turks, who are returning to Bulgaria after their recent out-migration. It is quite possible that one group of exiles (ethnic Bulgarians fleeing from the former Soviet Union) will be challenged by another group with a difficult exile experience (Bulgaria's ethnic Turks). Bulgarian refugees are allowed to stay in Bulgaria as long as nationalist groups can make use of them to shift the balance in existing ethnic conflicts. However, nothing yet suggests that the Bulgarian government is prepared to promptly deal with the issue of permanent resettlement for these refugees in a way that would protect them from new clashes. 10

\section{Notes}

1. Minko Minkov, at a workshop on "Bulgarian Emigration-Legal Issues," Sofia University, May 27, 1992.

2. Interview with Minko Minkov in Duma (September 19, 1992), 6.

3. W. Rogers Brubaker, "Citizenship Struggles in Soviet Successor States," International Migration Review 97 (1992), 270.

4. Blagovest Nyagoulov, "Ethnic Revival or Assimilation? To Presumably Half a Million Bulgarians in the ex-USSR, Life is a Sea 